\title{
ENTREPRENEURSHIP EDUCATION AND BUSINESS OPPORTUNITY EXPLOITATION: POSITIVE EMOTION AS MEDIATOR
}

\author{
Nor Hafiza Othman ${ }^{1,2}$, Norasmah Othman ${ }^{1 *}$, Noor Hasni Juhdi ${ }^{1}$ \\ ${ }^{1}$ Universiti Kebangsaan Malaysia, Malaysia \\ ${ }^{2}$ Universiti Malaysia Kelantan, Malaysia \\ *e-mail: lin@ukm.edu.my
}

\begin{abstract}
Entrepreneurship education is believed to facilitate students' competency development and enhance their self-employment potential. Students' involvement in entrepreneurship is influenced by their emotions, especially in the early stages of business start-ups. Without exploiting potential business opportunities, entrepreneurship will not occur. This study aims to determine positive emotion effects on the relationship between entrepreneurship education and business opportunity exploitation. The study's sample comprised of 152 final year university students. A questionnaire-based survey was the main instrument employed and the hypotheses developed were tested using Partial Least Squares-Structural Equation Modeling. The findings showed that the students' action to exploit opportunities was significant, and was affected by the exposure to entrepreneurial learning and anticipated effect of positive emotion on entrepreneurship. These findings confirmed that anticipated positive emotions are important throughout the entrepreneurial process and form a motivating factor to engage in entrepreneurial activities. Furthermore, the result showed that positive emotions partially mediated the relationship between entrepreneurship education and opportunity exploitation. This study is important for students to experience a paradigm shift towards entrepreneurship and to encourage them to select entrepreneurship as a career option. Future studies could explore the effect of anticipated negative emotions among tertiary education students, and potential entrepreneurs.
\end{abstract}

\section{Keywords: entrepreneurship education, positive emotion, opportunity exploitation}

\section{PENDIDIKAN KEWIRAUSAHAAN DAN EKSPLOITASI PELUANG BISNIS: EMOSI POSITIF SEBAGAI MEDIATOR}

\begin{abstract}
Abstrak: Pendidikan kewirausahaan dapat memfasilitasi pengembangan kompetensi siswa dan meningkatkan potensi wirausaha mereka. Keterlibatan siswa dalam kegiatan kewirausahaan dipengaruhi oleh emosinya, terutama pada tahap awal memulai bisnis. Tanpa mengeksploitasi peluang bisnis yang potensial, kewirausahaan tidak akan terjadi. Studi ini bertujuan untuk mengetahui efek emosi positif pada hubungan antara pendidikan kewirausahaan dan eksploitasi peluang bisnis. Sampel kajian ini terdiri dari 152 mahasiswa tahun terakhir. Survei berbasis kuesioner adalah instrumen utama yang digunakan. Hipotesis yang dikembangkan diuji menggunakan Partial Least Squares-Structural Equation Modeling. Hasil penelitian menunjukkan bahwa tindakan siswa untuk mengeksploitasi peluang adalah signifikan dan dipengaruhi oleh paparan pembelajaran kewirausahaan dan efek dari emosi positif yang diantisipasi pada kewirausahaan. Temuan ini menegaskan bahwa emosi positif yang diantisipasi penting selama proses kewirausahaan dan menjadi faktor pendorong untuk terlibat dalam kegiatan kewirausahaan. Selanjutnya, hasil menunjukkan bahwa emosi positif memediasi sebagian hubungan antara pendidikan kewirausahaan dan eksploitasi peluang. Studi ini penting bagi mahasiswa agar mengalami perubahan paradigma menuju kewirausahaan dan mendorong mereka untuk memilih kewirausahaan sebagai pilihan karir. Penelitian yang selanjutnya dapat mengeksplorasi efek dari emosi negatif yang diantisipasi di antara siswa pendidikan tinggi, dan khususnya pengusaha potensial.
\end{abstract}

\section{Kata Kunci: pendidikan kewirausahaan, emosi positif, eksploitasi peluang}




\section{INTRODUCTION}

Entrepreneurship plays an important role in the economic development process and it maintains the country's competitiveness in the face of globalization challenges. The impact of globalization on economy has evolved through various phases of development experience. According to Lee (2019), Malaysia's economic development is driven and shaped by globalization, from the pre-colonial and postindependence. Consequently, similar to any countries worldwide, Malaysia cannot avoid the economic and cultural challenges rising from globalization (Othman \& Othman, 2015). Among others, the effects of globalization extend to entrepreneurship, which is a form of today's business that is not limited merely to business arrangements involving goods or services, yet they also include business activities like marketing and technology. This situation presents opportunities and challenges to entrepreneurs when they expand their businesses, without being limited by the constraints of geographical boundaries. Therefore, globalization trend is more likely to leverage information and communication technology as a catalyst for national development.

The entrepreneurship process begins when an individual recognizes and exploits opportunities in an uncertain environment (Bakker \& Shepherd, 2017). By seeking business opportunities, entrepreneurs can identify new ways of producing products and services, or improve existing products. This is acknowledged by Kuckertz, Kollmann, Krell, \& Stockmann (2017) who stated that an entrepreneur will leverage opportunities, and that a successful entrepreneur will possess the ability to do so (Short, Ketchen, Shook, \& Ireland, 2010). Moreover, while globalization promises opportunities for entrepreneurs, it also demands drastic changes to ensure that they can compete in the global economic market. Thus, entrepreneurs aiming to explore the international market must change their mindsets and think globally in order to be able to apply different strategies for countries with different social, political, and economic characteristics.

According to Renko, Shrader, \& Simon (2012), individuals use the mental model as a filter of knowledge through real market signals and it will process and perceive perceptions of entrepreneurial opportunities. More specifically, identifying potential entrepreneurial opportunities is done to interpret different market signals through knowledge structures that operate as perception filters (Baron, 2006). Incompatibility between market signals and knowledge structures results in inhibition of market signals (Renko et al., 2012). Some researchers have described the characteristics of opportunity exploitation through planning, networking, and searching for resources (Kuckertz et al., 2017; Shane \& Venkaraman, 2000), and individuals with more information resources will have greater capacity to exploit those opportunities (Wood, 2017). Therefore, the process of assessing opportunities determines whether such opportunities are exploited or not.

In addition, globalization has created a competitive and challenging global environment for entrepreneurs to track and seize opportunities available in the open market. This means, individuals who are sensitive to the environment will know or recognize more opportunities that can be exploited. Hence, exposure to entrepreneurship-oriented knowledge and experience can increase students' awareness of entrepreneurship, which is important given the increasing number of unemployed graduates each year. This is supported by Ooi \& Nasiru (2015), who stated that uncertain global economic changes affect the provision of job opportunities, which are increasingly limited to graduates. Indirectly, the number of unemployed graduates will increase, and this situation requires them to be wiser in preparing themselves to compete in the globalization era.

Entrepreneurship education has developed a positive perception among university students about business viability (Bae, Qian, Miao, \& Fiet, 2014; Jones \& English, 2004), how to control over the future, and putting creativity into practice (Baron, 2008; Ferreira, Loiola, \& Gondim, 2017). Entrepreneurship education is often defined as the development of students' capabilities, such as entrepreneurial knowledge, attitudes, and skills (Ahmed, Chandran, \& Klobas, 2017; Hutasuhut, Irwansyah, Rahmadsyah, \& Aditia, 2020; Lackeus, 2015) to establish a new business (Karimi, Biemans, Lans, Chizari, \& Mulder, 2016; Kuckertz et al., 2017). Apart from capability development, entrepreneurship education can aid an individual to adapt more 
quickly (Echols, 2010). This study is based on one of the most widely used theories, namely the theory of human capital, which is related to the desire and ability to engage in entrepreneurship (Unger, Rauch, Frese, \& Rosenbusch, 2011). Human capital theory predicts that individuals or groups who possess higher levels of knowledge, skills, and other competencies will achieve better results than those with lower levels (Ployhart \& Moliterno, 2011). Therefore, entrepreneurship education has become the main focus of the Ministry of Education, targeting students at the primary, secondary, and tertiary levels.

However, unemployment is rising each year, reaching $3.4 \%$ in 2016 - an increase of $.3 \%$ over the previous year (Department of Statistics Malaysia, 2017). This issue affects the country as the high unemployment rate is a liability to Malaysia and its people, and it highlights the fact that graduates need to think as job creators rather than job seekers. Thus, the Ministry of Higher Education (MOHE) launched the Entrepreneurship Development Policy as a step towards promoting human capital development in producing graduate entrepreneurs (MOHE, 2010). The main goal of this policy is to produce quality human capital and to encourage entrepreneurial thoughts, attributes, and values (MOHE, 2010). Although the number of graduates becoming entrepreneurs in Malaysia has increased, the percentage of the increase remains relatively small. According to the Economic Planning Unit (2015), the percentage of graduates engaging in business increased by .6\% in 2013 , but the share was very small compared to $1.4 \%$ in 2012 , despite various government initiatives made, and incentives given, to encourage students and graduates to become entrepreneurs.

This can be attributed to individual emotions in forming judgments or decisions, especially related to entrepreneurship engagements. The importance of entrepreneurial emotions in carrying out entrepreneurial activities is agreed upon by Lackeus (2014) and Kollmann, Stockmann, \& Kensbock (2017). The activity of entrepreneurship is reflected as a journey in the face of uncertainty and risks, which will affect an individual's emotion (Cardon, Foo, Shepherd, \& Wiklund, 2012). Then, they applied psychological theory and studied the importance of emotion at the entrepreneurship process. This situation can be observed when an entrepreneur needs to make any decision or action, even in the context of uncertainty and changing market conditions that require them to do so. This explains that with positive emotions, one can control the situation and survive with the action in the future. Thus, this development is relevant to entrepreneurship education, as there is an incentive for entrepreneurship lecturers to enhance students' positive attitude towards entrepreneurship, and to make teaching and learning process become more effective.

Besides that, Miltenberger (2001) stated that entrepreneurial behaviour can be influenced systematically through events that occur in the individual's environment. Given this, business opportunity exploitation is an entrepreneurial action involving strategic planning to seize potential opportunities to start a business. In exploiting a business opportunity, the ability or willingness to mobilize resources and control new organizations are important (Dahlqvist \& Wiklund, 2012). Furthermore, studies on entrepreneurial behaviours or actions, like exploiting business opportunities, are scarce (Wood, 2017). Without any action to exploit opportunities, the quest for potential opportunities would be useless. Indirectly, the exposure of entrepreneurship education can improve the quality of students, who in turn, would be more confident in conducting entrepreneurship activities.

According to Cardon et al. (2012), entrepreneurial activity is considered as a journey of concern with uncertainty and unexpected risks, and this will affect entrepreneurs' emotions. All activities such as introducing products and services in the market, gathering resources and business opportunities involve risks, demanding multiple stages of planning, and may even help to diversify among entrepreneurs (Ferreira et al., 2017). These situations can be observed when they need to make any decision or undertake any action in the context of ever-changing uncertainties and market conditions, which warrant actions. As such, with positive emotions, they can control the situation and ensure future survival. Positive emotions involve a pleasurable reaction to an act including joy, hope, satisfaction, excitement, and happiness (Foo, 2011; Kerr, Chin, \& Brodrick, 2019). In fact, positive emotions would boost 
an individual's effectiveness in both career and life. Thus, the anticipated emotions of potential entrepreneurs play a very important role in preparing them to become job creators.

Furthermore, the study of emotion has been acknowledged by previous researchers, especially in psychology (Joseph \& Newman, 2010), yet, less attention has been paid to it in entrepreneurship (Cardon et al., 2012) notwithstanding that all entrepreneurs' decisions are based on what they feel about the subject or matter under consideration. Emotions are found to influence the ability of entrepreneurs to face uncertainty (Cacciotti, Hayton, Mitchell, \& Giazitzoglu, 2016; Ucbasaran, Westhead, Wright, \& Flores, 2010) in assessing and subsequently making decisions (Welpe, Sporrle, Grichnik, Michl, \& Audretsch, 2012; Zampetakis, Kafetsios, \& Moustakis, 2017). This is supported by Hayton \& Chalakova (2012) who maintained that research had recently begun to think about how people "feel" as opposed to how or what they "think". This situation is aligned with today's challenging and dynamic business environment. Thus, anticipated emotions are important, and they affect individuals' decisionmaking and achievement.

In addition, a range of emotions are expected to determine entrepreneurial behaviors or decisions (Baron, 2008; Zampetakis et al., 2017), and it is relevant for these to be measured for university students, in equipping them to choose entrepreneurship as a career (Hodzic, Ripoll, Lira, \& Zenasni, 2015; Othman, Othman, \& Juhdi, 2019). A study conducted by Foo (2011) on the influence of emotions on business opportunity shows that students' emotions influence perceptions and risk choices in evaluating business opportunities. Whereas, Welpe et al. (2012) stated that happy emotions affect the impact of valuation on business opportunities exploitation. This is to clarify that higher positive emotions will increase the impact assessment of entrepreneurial opportunities. Furthermore, positive emotions are able to overcome stress, and increase creativity and heuristic processing (Baron, 2008; Wangid, 2004). Thus, it is important to identify students ' emotions whether they promote or become an obstacle to starting a business, despite the university's many entrepreneurial initiatives to facilitate entrepreneurship. Therefore, the main purpose of this study is to determine the mediating effect of positive emotions on the relationship between entrepreneurship education and opportunity exploitation among university students.

\section{METHODS}

This study employs a survey-based questionnaire as the main instrument. The questionnaire covers four parts, whereby the first section covers the respondent's profile, the second section is related to entrepreneurship education, the third section covers business opportunity exploitation, and the last section covers positive emotions. In this study, entrepreneurship education was measured on a ten-point scale while a seven-point scale was employed for items related to business opportunity exploitation and positive emotions. Additionally, 12 items related to entrepreneurship education were adapted from Lackeus (2015); Othman \& Othman (2017), business opportunity exploitation had seven items adapted from Kuckertz et al. (2017), and positive emotions were measured through five items that were modified based on a study by Foo (2011).

Eight experts were involved in the content validity to get their consent for each concept and item used in the questionnaire. Based on the content validity index for each item (I-CVI), the value of entrepreneurship education was .922 , positive emotion (.927) and opportunity exploitation (.903). The results showed that the content of the questionnaire had good validity as the value was greater than .90 (Stewart \& Haswell, 2013). Prior to the pilot study, face validity was performed by all experts and 20 final year students. After getting their views, some confusing sentences were identified, and improvements to the questionnaires were carried out.

After that, a pilot study was conducted to 40 final year students to test the reliability of the questionnaire. The Cronbach's alpha value for entrepreneurship education was .89 , business opportunity exploitation was .88 , and positive emotion was .91 . Based on the results, all variables exceeded the threshold value of .6 (Sekaran \& Bougie, 2016). Thus, this instrument was reliable to be used in the actual research. Next, a survey was conducted to final year students pursuing their first degree from a public 
university. This study used a purposive sampling technique, focusing on final year students only, as they would be actively planning for their postgraduation career.

This study predicts the relationships between the variables used in the research model. This study follows the transmittal approach recommended by Rungtusanatham, Miller, \& Boyer (2014) to test the mediation effect. Figure 1 shows the developed research model. Two hypotheses are proposed in this model:

H1: Entrepreneurship education has an effect on business opportunity exploitation

H2: Positive emotion mediates the relationship between entrepreneurship education and business opportunity exploitation

In this study, GPower software introduced by Faul, Erdfelder, Lang, \& Buchner (2007) was used to calculate the minimum sample size, setting the effect size at .15 , and required power at .95 . Accordingly, the minimum number of required respondents was 89 . A total of 160 questionnaires were distributed and 152 complete questionnaire responses were collected, yielding a response rate of 95 percent. The data collected were analyzed using IBM SPSS version 22 and Smart PLS version 3.0, employing variancebased structural equation modeling (SEM) to test the hypotheses.

\section{FINDINGS AND DISCUSSION Findings}

In this section, the findings covered the respondents' data and analysis of SEM in testing the developed hypotheses. Majority of the students in this study were females (75.7\%), with only $24.3 \%$ being males. Most of them were taking Social Science courses $(49.3 \%)$, followed by Science (28.3\%) and Technical courses $(22.4 \%)$. All students had taken an entrepreneurship course in their first year of study, and the majority of them $(78.3 \%)$ had some business experiences.

There are two types of models involved in SEM: measurement model and structural model. For measurement model, two types of validity were assessed in this study: (i) convergent validity, and (ii) discriminant validity. Factor loadings and Average Variance Extracted (AVE) were used to test convergent validity. A positive test requires that the factor loadings should exceed .70, and Composite Reliability (CR) should exceed .5 (Hair, Hult, Ringle, \& Sarstedt, 2014). Table 1 shows that both criteria are met. All the loading values were above the cut-off of .70. However, A2 was deleted because its loading value (.672) was less than .7. In addition, each of the constructs had an AVE value of greater than .5. Therefore, each of the constructs meets the requirements for convergent validity and internal consistency.

Next, discriminant validity was assessed based on Fornell \& Larcker's (1981) approach as described in Ramayah, Cheah, Chuah, Ting, $\&$ Memon (2018). This approach suggests that a construct should have a stronger loading than the other constructs, while the average variance of the construct should exceed the variance between any other construct, and itself. Table 2 compares the square root of the AVE with the correlations. All constructs displayed sufficient discriminant validity, with the square root of the AVE being larger than the correlations for each construct. Overall, in this study, the measurement model presents adequate convergent validity and discriminant validity.

The structural model can be assessed based on the explanatory power of the model (R2), path coefficient, and effect size ( $f 2$ ) (Hair et

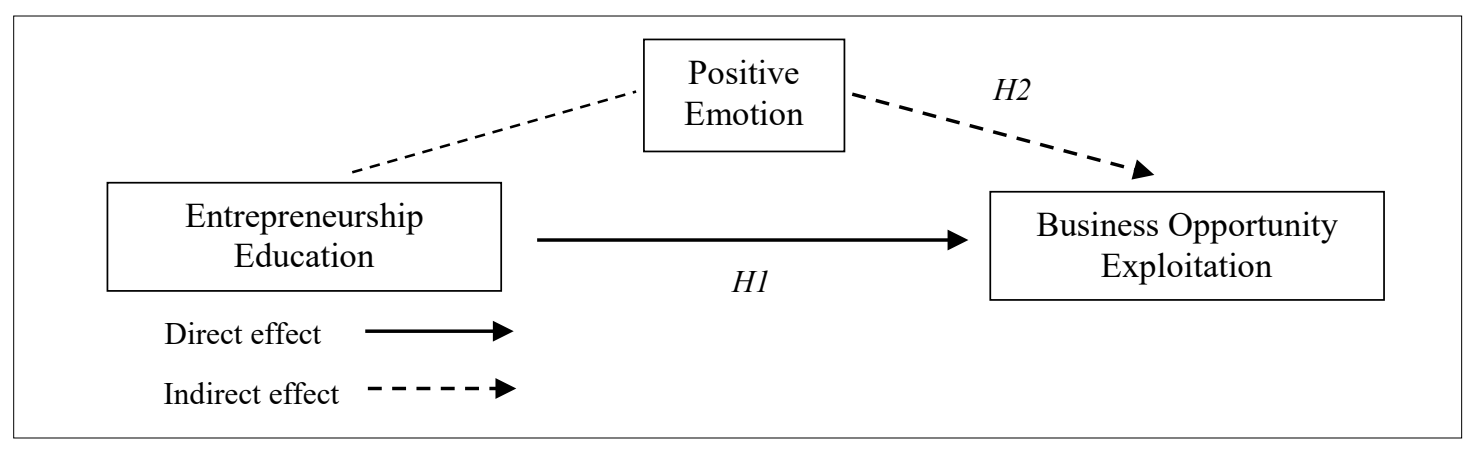

Figure 1. Research model 
Table 1. Measurement Model

\begin{tabular}{|c|c|c|c|c|}
\hline Construct & Item & Loadings & AVE & CR \\
\hline \multirow[t]{11}{*}{ Entrepreneurship education } & A1 & .704 & .567 & .935 \\
\hline & A2 & .781 & & \\
\hline & A3 & .718 & & \\
\hline & A4 & .806 & & \\
\hline & A5 & .790 & & \\
\hline & A6 & .718 & & \\
\hline & A7 & .790 & & \\
\hline & A 8 & .712 & & \\
\hline & A9 & .772 & & \\
\hline & A10 & .746 & & \\
\hline & A11 & .741 & & \\
\hline \multirow[t]{7}{*}{ Business opportunity exploitation } & B1 & .832 & .708 & .944 \\
\hline & B2 & .850 & & \\
\hline & B3 & .846 & & \\
\hline & B4 & .828 & & \\
\hline & B5 & .876 & & \\
\hline & B6 & .864 & & \\
\hline & B7 & .792 & & \\
\hline \multirow[t]{5}{*}{ Positive emotion } & $\mathrm{C} 1$ & .871 & .813 & .956 \\
\hline & $\mathrm{C} 2$ & .923 & & \\
\hline & $\mathrm{C} 3$ & .921 & & \\
\hline & $\mathrm{C} 4$ & .913 & & \\
\hline & $\mathrm{C} 5$ & .880 & & \\
\hline
\end{tabular}

Table 2. Discriminant Validity

\begin{tabular}{lccc}
\hline & $\begin{array}{c}\text { Entrepreneurship } \\
\text { Education }\end{array}$ & $\begin{array}{c}\text { Business } \\
\text { Opportunity } \\
\text { Exploitation }\end{array}$ & $\begin{array}{c}\text { Positive } \\
\text { Emotion }\end{array}$ \\
\hline Entrepreneurship education & .753 & & \\
Business opportunity exploitation & .570 & .842 & \\
Positive emotion & .436 & .444 & .902 \\
\hline
\end{tabular}

al., 2014). Table 3 displays the results of testing for direct effects between entrepreneurship education and opportunity exploitation. It was found that entrepreneurship education $(\beta=$ $.464, t=7.926, p<.05)$ had a positive effect on opportunity exploitation with an explained variance of $37.2 \%$, while the effect size indicated that this effect was moderate $(f 2=.278)$. Thus, $H 1$ is supported in this study.

Besides that, this study employed bootstrapping for the mediation analysis. The bootstrapping analysis was used to determine the loading and path coefficients based on a resample size of 5,000 (Hair et al., 2014). In terms of indirect effects, the finding showed that hypothesis $H 2$ was supported (see Table 4). This indicated that the indirect effect was significant $(\beta=.105, t=3.395, p<.05)$. Based on Hair et al. (2014), the VAF was used to determine the relative size of the indirect effect to the total effect. The result showed that the VAF was $50.12 \%$ - indicating partial mediation. Therefore, there was a mediating effect of positive emotions on the relationship between entrepreneurship education and opportunity exploitation. 
Table 3. Hypothesis Testing of Direct Effects

\begin{tabular}{llcccccc}
\hline & \multicolumn{1}{c}{ Relationship } & Coefficient & $\begin{array}{c}\text { Std. } \\
\text { Error }\end{array}$ & t-value & Decision & $\boldsymbol{R}^{2}$ & $\boldsymbol{f}^{2}$ \\
\hline$H 1$ & $\begin{array}{l}\text { Entrepreneurship } \\
\text { education } \rightarrow \text { Business } \\
\text { opportunity exploitation }\end{array}$ & .464 & .059 & 7.926 & Supported & .372 & .278 \\
\hline
\end{tabular}

Table 4. Hypothesis Testing of Indirect Effects

\begin{tabular}{|c|c|c|c|c|c|c|c|}
\hline & \multirow[t]{2}{*}{ Relationship } & \multirow[t]{2}{*}{ Coefficient } & \multirow{2}{*}{$\begin{array}{l}\text { Std. } \\
\text { Error }\end{array}$} & \multirow[t]{2}{*}{ t-value } & \multicolumn{2}{|c|}{$\begin{array}{c}\text { Confidence } \\
\text { Interval (BC) }\end{array}$} & \multirow[t]{2}{*}{ Decision } \\
\hline & & & & & $\mathbf{L L}$ & $\mathbf{U L}$ & \\
\hline$H 2$ & $\begin{array}{l}\text { Entrepreneurship } \\
\text { education } \rightarrow \text { Positive } \\
\text { emotion } \rightarrow \text { Business } \\
\text { opportunity exploitation }\end{array}$ & .105 & .031 & 3.395 & .045 & .167 & Supported \\
\hline
\end{tabular}

\section{Discussion}

The first result showed that the exposed entrepreneurship education to the students had a positive effect on their actions to exploit business opportunities. This clearly shows that exposing individuals to various forms of experience and knowledge can help them improve their ability to exploit entrepreneurial opportunities. This is consistent with previous studies that indicated entrepreneurship education can increase a student's ability and his/her tendency to engage in entrepreneurship (Jiang \& Wang, 2014; Lackeus 2015; Othman \& Othman, 2015; Sanchez \& Sahuquillo, 2018). This is acknowledged by Li \& Wu (2019) that students who have completed an entrepreneurship module or entrepreneurship course are more possible to choose an entrepreneur career than students who do not. Therefore, higher education institutions play an important role in ensuring that entrepreneurship education can cultivate the potential of entrepreneurs to recognize and exploit opportunities, and then venture into entrepreneurship.

Human capital theory supports the view that education can enhance entrepreneurial thinking and skills to produce optimal outcomes (Martin, McNally, \& Kay, 2013), and this is consistent with Malaysia's NEP to create individuals who are intellectually, spiritually, emotionally, and physically balanced and harmonious. Consequently, entrepreneurship education has become the main focus of the
Ministry of Education, targeting students at primary, secondary, and tertiary levels. Besides that, the experimental and theoretical approaches that are well designed for entrepreneurship education is important to develop entrepreneurial capability to recognize business opportunities, and subsequently embark on a new venture. This is in line with the findings of Karimi et al. (2016), that the ability to recognize opportunities can be developed through entrepreneurship education. This can be seen when students are more likely to generate ideas and innovative business ideas in experimental groups, while the controlled groups do not show any significant changes in business idea generation. Therefore, experiential learning was recognized to be capable of producing entrepreneurial attributes, mindset, and behaviours.

In addition, the second finding showed that positive emotion is a mediator between the relationship of entrepreneurship education and business opportunity exploitation. The relative size indicated positive emotions as a partial mediator of the relationship between entrepreneurship education and business opportunity exploitation when the VAF obtained is $50.12 \%$. This is supported by some previous studies that revealed the importance of emotions to entrepreneurs' behaviour, and especially the effect of emotion on the evaluation and exploitation of opportunities (Foo, 2011; Welpe et al., 2012). Based on Foo (2011), positive emotions involve a pleasurable reaction to an 
act including joy, hope, satisfaction, excitement, and happiness. In fact, positive emotions would boost an individual's effectiveness in both career and life. Thus, the anticipated emotions of potential entrepreneurs play a very important role in preparing them to become job creators.

Besides that, this study has shown that positive emotions are important in increasing student involvement in entrepreneurship. In other words, when making judgments and decisions, each individual will take their feelings into account. The result is supported by Baron (2008), and Foo (2011) who showed that positive emotions may boost entrepreneurial creativity including entrepreneurial opportunity, thereby increasing the likelihood that the individual seeks. and exploits potential opportunities. Indirectly, students who have positive emotions with respect to entrepreneurial activity would be more committed to starting a business. Indeed, Cacciotti et al. (2016) and Hayton \& Cholakova (2012) stated that entrepreneurs experience anxiety at various points throughout the entrepreneurial process, whenever they have to make any decision or undertake an action in an uncertain environment with constantly changing market conditions that require them to do so. Henceforth, when students have a clear emotion, this can help them to make a judgment in certain activities relating to entrepreneurship.

Indirectly, individuals who cannot control their emotions would find that their emotions become a barrier to starting a business. This is in line with Cardon et al. (2012), and Othman et al. (2019) that in carrying out entrepreneurship activities, every single incident is uncertain, and the risks involved will affect their emotions. Some researchers stated that emotions are important in determining entrepreneurial behavior (Baron, 2008; Hodzic et al., 2015; Welpe et al., 2012; Zampetakis et al., 2017) and the students will be more willing to become entrepreneurs. For example, when an individual is happy, they will have an inductive judgment and this could enhance creativity in producing a product. This means, anticipated emotions are vital in taking an entrepreneurial action, and thus engage in business. Therefore, anticipated emotions have the advantage of influencing behavior, and the exposure to entrepreneurship education is important in term of affecting the students' emotions towards entrepreneurship.
Furthermore, entrepreneurship education positively influences graduates attending entrepreneurship courses to start a new business (Ahmed et al., 2017; Jones \& English, 2004; Kuckertz et al., 2017). Developing entrepreneurship education curriculum or syllabus is important as it does not emphasize the cognitive aspects only, but it also addresses affective needs. This is aligned with the NEP to create individuals who are intellectually, spiritually, emotionally, and physically balanced and harmonious. Potential entrepreneurs need to learn to utilize their emotions; their perceptions can affect their ability to recognize and respond to entrepreneurial opportunities (Foo, 2011; Karimi et al., 2016; Welpe et al., 2012). This is explained by Kuckertz et al. (2017) that an entrepreneur will take advantage of opportunities and exploit them. Students are more involved in the planning process, including evaluating and analyzing using different approaches to the business models they aspire to, as well as evaluating the resources to invest (Ferreira et al., 2017). Therefore, imparting entrepreneurship education to students is important to improve the overall quality of entrepreneurs, who would be better prepared for any possibility.

\section{CONCLUSION}

Positive emotions are a pleasant response to any actions taken in entrepreneurship activities. This means, having positive emotions will help the students to succeed in their career or life. These findings highlighted that positive emotion partially mediates the relationships between entrepreneurship education and business opportunity exploitation. In this regard, students' entrepreneurial ability through entrepreneurial learning will influence their emotions in making decisions to start a business, and eventually venture into entrepreneurship. In other words, the exposure of entrepreneurship education will inspire students to pursue entrepreneurship. Therefore, positive emotions will help enable an individual to act and raise them to choose entrepreneurship as a career.

Furthermore, entrepreneurship education does not only disseminate knowledge on entrepreneurship, yet, it also improves entrepreneurial attitudes and perceptions toward entrepreneurship. The findings show that entrepreneurship education contributes to 
students who are involved in business. Through entrepreneurship education, students' knowledge and self-confidence are increased and their abilities to recognize opportunities are higher than those without formal entrepreneurship education. This is related to the students' emotional assessments, which could be positive or negative towards entrepreneurial activity. Thus, the study of the effects of positive emotions is important to improve motivation and perceptions to be involved in business at an early stage.

Furthermore, emotion is a critical factor in the entrepreneurship process, entrepreneurs experience anxiety throughout this process. The findings of this study have implications for both universities and policy makers. Instructors and lecturers need to provide appropriate teaching and learning materials to attract students towards entrepreneurship. Digital videos or multimedia can be alternatives to traditional techniques in entrepreneurial learning. In addition, the entrepreneurship education syllabus should provide the latest knowledge and skills to students, including technology and marketing. This is aligned with the advantages gained from a borderless world, such as e-commerce, which opens up new markets for businesses. Therefore, more potential entrepreneurs will be involved in the planning of undertaking entrepreneurship activities and this will help them to understand the tolerance for risk and uncertainty.

Moreover, this study hypothesized a new mediation effect, specifically, positive emotions serve as a mediator of the relationship between entrepreneurship education and business opportunity exploitation. The findings show the role of emotions in making decisions and undertaking entrepreneurial actions. Specifically, the results explain that with positive emotions, one can control the situation and ensure future survival, particularly ensuring business sustainability. Furthermore, the use of positive emotions in a timely manner is one way that intelligent people use, to be in control of their emotions. Therefore, someone with high positive emotions will be more resilient in dealing with a crisis or problem especially in the field of entrepreneurship.

There are some limitations in this study. Firstly, this study involved only a small number of samples from a university. Future research may increase the sample size of final year students from several universities to generalize the findings. Next, this study put primary focus on the positive emotion towards business opportunity exploitation only. Future research could determine the anticipated negative emotion among students in higher learning institutions, specifically among potential entrepreneurs. This is important to identify whether the students' emotions encourage or impede them from starting up, following the many entrepreneurial activities undertaken by the university to cultivate entrepreneurship among them. Furthermore, the entrepreneurial process is dynamic and challenging, especially in business start-up among students. Therefore, this study is highly relevant to university students to encourage them to choose entrepreneurship as a career.

\section{ACKNOWLEDGEMENT}

The authors would like to thanks the Faculty of Education, Universiti Kebangsaan Malaysia for funding the research grant GG-218-012.

\section{REFERENCES}

Ahmed, T., Chandran, V. G. R., \& Klobas, J. (2017). Specialized entrepreneurship education: Does it really matter? Fresh evidence from Pakistan. International Journal of Entrepreneurial Behavior \& Research, 23(1), 4-19. doi:10.1108/ IJEBR-01-2016-0005.

Bae, T. J., Qian, S., Miao, C., \& Fiet, J. O. (2014). The relationship between entrepreneurship education and entrepreneurial intention. A meta-analytic review. Entrepreneurship Theory and Practice, 38(2), 217-254. doi:10.1111/etap.12095.

Bakker, R. M., \& Shepherd, D. A. (2017). Pull the plug or take the plunge: Multiple opportunities and the speed of venturing decisions in the Australian mining industry. Academy of Management Journal, 60(1), 130-155. doi:10.5465/amj.2013.1165.

Baron, R. A. (2006). Opportunity recognition as pattern recognition: How entrepreneurs "connect the dots" to identify new business opportunities. Academy of 
Management Perspectives, 20(1), 104119. doi:10.5465/amp.2006.19873412.

Baron, R. A. (2008). The role of affect in the entrepreneurial process. Academy of Management Review, 33(2), 328-340. doi:10.2307/20159400.

Cacciotti, G., Hayton, J. C., Mitchell, J. R., \& Giazitzoglu, A. (2016). A reconceptualization of fear of failure in entrepreneurship. Journal of Business Venturing, 31(3), 302-325. doi:10.1016/j. jbusvent.2016.02.002.

Cardon, M. S., Foo, M. D., Shepherd, D., \& Wiklund, J. (2012). Exploring the heart: Entrepreneurial emotion is a hot topic. Entrepreneurship Theory and Practice, 36(1), 1-10. doi:10.1111/j.15406520.2011.00501.x.

Dahlqvist, J., \& Wiklund, J. (2012). Measuring the market newness of new ventures. Journal of Business Venturing, 27(1), 185196. doi:10.1016/j.jbusvent.2010.12.001.

Department of Statistics Malaysia. (2017). Malaysia labour statistics.

Echols, D. G. (2010). The relationship between post-secondary international business education and American expatriate managerial success (Research Report, University of Phoenix).

Economic Planning Unit. (2015). Educational transformation strategy paper. Putrajaya, Malaysia: Author.

Faul, F., Erdfelder, E., Lang, A., \& Buchner, A. G. (2007). G*Power 3: A flexible statistical power analysis program for the social, behavioral, and biomedical sciences. Behavior Research Methods, 39(2), 175191. doi:10.3758/BF03193146.

Ferreira, A. D. S. M., Loiola, E., \& Gondim, S. M. G. (2017). Motivation, business planning and risk management: entrepreneurship among university students. Revista de Administracoa Inovvacao, 14(1), 140150. doi:10.1016/j.rai.2017.03.003.

Foo, M. D. (2011). Emotions and entrepreneurial opportunity evaluation. Entrepreneurship: Theory and Practice, 35(2), 375-393. doi:10.1111/j.1540-6520.2009.00357.x.

Fornell, C., \& Larcker, D. F. (1981). Evaluating structural equation models with unobservable variables and measurement error. Journal of Marketing Research, 18(1), 39-50. doi:10.2307/3151312.

Hair, J. F., Hult, G. T. M., Ringle, C. M., \& Sarstedt, M. (2014). A Primer on Partial Least Squares Structural Equation Modeling (PLS-SEM) (4 ${ }^{\text {th }}$ ed.). Thousand Oaks, CA: Sage.

Hayton, J. C., \& Cholakova, M. (2012). The role of affect in the creation and intentional pursuit of entrepreneurial ideas. Entrepreneurship Theory and Practice, 36(1), 41-68. doi:10.1111/j.15406520.2011.00458.x.

Hodzic, S., Ripoll, P., Lira, E., \& Zenasni, F. (2015). Can intervention in emotional competences increase employability prospects of unemployed adults? Journal of Vocational Behavior, 88(6), 28-37. doi:10.1016/j.jvb.2015.02.007.

Hutasuhut, S., Irwansyah, Rahmadsyah, A., \& Aditia, R. (2020). Impact of business models canvas learning on improving learning achievement and entrepreneurial intention. Cakrawala Pendidikan, 39(1), 168-182. doi:10.21831/cp.v39i1.28308.

Jiang, Z., \& Wang, Z. (2014). Entrepreneurial intention and outcome expectancy: Evidence from South Korea and China. Contemporary Management Research, 10(3), 251-270. doi:10.7903/cmr.12012.

Jones, C., \& English, J. (2004). A contemporary approach to entrepreneurship education. Education + Training, 46(8/9), 416-423. doi:10.1108/00400910410569533.

Joseph, D. L., \& Newman, D. A. (2010). Emotional intelligence: An integrative meta-analysis and cascading model. Journal of Applied Psychology, 95(1), 5478. doi:10.1037/a0017286. 
Karimi, S., Biemans, J. A., Lans, T., Chizari, M., \& Mulder, M. (2016). The impact of entrepreneurship education: A study of Iranian students' entrepreneurial intentions and opportunity identification. Journal of Small Business Management, 5(3), 299-307. doi:10.1111/jsbm.12137.

Kerr, K. T., Chin, T. C., \& Brodrick, D. V. (2019). Positive education and the new prosperity: Exploring young people's conceptions of prosperity and success. Australian Journal of Education, 63(2), 1-18. doi:10.1177/0004944119860600.

Kollmann, T., Stockmann, C., \& Kensbock, J. M. (2017). Fear of failure as a mediator of the relationship between obstacles and nascent entrepreneurial activity: An experimental approach. Journal of Business Venturing, 32(3), 280-301. doi:10.1016/j.jbusvent.2017.02.002.

Kuckertz, A., Kollmann, T., Krell, P., \& Stockmann, C. (2017). Understanding, differentiating, and measuring opportunity recognition and opportunity exploitation. International Journal of Entrepreneurial Behavior \& Research, 23(1), 78-97. doi:10.2139/ssrn.2099011.

Lackeus, M. (2014). An emotion based approach to assessing entrepreneurial education. International Journal of Management Education, 12(3), 374-396. doi:10.1016/j. ijme.2014.06.005.

Lackeus, M. (2015). Entrepreneurship in education: What, why, when, how. Entrepreneurship360 Background Paper, OECD, France.

Lee, C. (2019). Globalisation and economic development: Malaysia's experience (Report number: ERIA Discussion Paper Series No. 307, Economic Research Institute for ASEAN and East Asia). https://www.eria.org/uploads/media/ discussion-papers/Globalisation-andEconomic-Development-MalaysiaExperience.pdf.

Li， L., \& Wu, D. (2019). Entrepreneurial education and students' entrepreneurial intention: does team cooperation matter? Journal of Global Entrepreneurship Research, 9(35), 1-13. doi:10.1186/ s40497-019-0157-3.

Martin, B. C., McNally, J. J., \& Kay, M.J. (2013). Examining the formation of human capital in entrepreneurship: A meta-analysis of entrepreneurship education outcomes. Journal of Business Venturing, 28(2), 211224. doi:10.1016/j.jbusvent.2012.03.002.

Miltenberger, R. G. (2001). Behavior modification: Principles and procedures $\left(2^{\text {nd }}\right.$ ed. $)$ Belmont, CA: Thomson Learning.

Ministry of Higher Education (MOHE). (2010). Entrepreneurship development policy institution of higher education.

Ooi, Y. K., \& Nasiru, A. (2015). Entrepreneurship education as a catalyst for business startups: A study on Malaysian community college students. Asian Social Science, $11(18), \quad 350-363 . \quad$ doi:10.5539/ass. v11n18p350.

Othman, N., \& Othman N. H. (2015). Relationship between entrepreneurial intentions and entrepreneurial career choice behavior among university students. Journal of Business and Economics, 6(1), 179-186. doi:10.15341/ jbe(2155-7950)/01.06.2015/017.

Othman, N., \& Othman, S. H. (2017). The perception of public university students of entrepreneurship education in Malaysia. International Business Management, 11(4), 865-873. doi:10.36478/ ibm.2017.865.873.

Othman, N. H., Othman, N., \& Juhdi, N. H. (2019). Determining the validity and realiability of entrepreneurial emotion. Academy of Entrepreneurship Journal, 25(3), 1-5. doi:1528-2686-25-3-275.

Ployhart, R. E., \& Moliterno, T. P. (2011). Emergence of the human capital resources: A multilevel model. Academy of Management Review, 36(1), 127-150. doi:10.5465/AMR.2011.55662569. 
Ramayah, T., Cheah, J., Chuah, F., Ting, H., \& Memon, M. A. (2018). Partial Least Squares Structural Equation Modeling (PLS-SEM) using SmartPLS 3.0. Kuala Lumpur: Pearson Malaysia.

Renko, M., Shrader, R. C., \& Simon, M. (2012). Perception of entrepreneurial opportunity: A general framework. Management Decision, 50(7), 1233-1251. doi:10.1108/00251741211246987.

Rungtusanatham, M., Miller, J. W., \& Boyer, K. K. (2014). Theorizing, testing and concluding for mediation in SCM research: Tutorial and procedural recommendations. Journal of Operations Management, 32(3), 99113. doi:10.1016/j.jom.2014.01.002.

Sanchez, V. B., \& Sahuquillo, C. A. (2018). Entrepreneurial intention among engineering students: The role of entrepreneurship education. European Research on Management and Business Economics, 24(4), 53-61. doi:10.1016/j. iedeen.2017.04.001.

Sekaran, U., \& Bougie, R. (2016). Research methods for business: A skill building approach. United Kingdom: John Wiley \& Sons.

Shane, S., \& Venkataraman, S. (2000). The promise of entrepreneurship as a field of research. Academy of Management Review, 25(1), 21-26. doi:10.5465/ amr.2000.2791611.

Short, J. C., Ketchen, D. J., Shook, C. L., \& Ireland, R. D. (2010). The concept of "opportunity" in entrepreneurship research: Past accomplishments and future challenges. Journal of Management, 36(1), 40-65. doi:10.1177/0149206309342746.

Stewart, J. J., \& Haswell, K. (2013).Assessing readiness to work in Primary Health Care: The content validity of a Self-check tool for physiotherapists and other health professionals. Journal of Primary Health Care, 5(1), 70-73. http://hdl.handle. net/10292/6087.

Ucbasaran, D., Westhead, P., Wright, M., \& Flores, M. (2010). The nature of entrepreneurial experience, business failure, and comparative optimism. Journal of Business Venturing, 25(1), 541555. doi:10.1016/j.jbusvent.2009.04.001.

Unger, J. M., Rauch, A., Frese, M., \& Rosenbusch, N. (2011). Human capital and entrepreneurial success: A metaanalytical review. Journal of Business Venturing, 26(3), 341-358. doi:10.1016/j. jbusvent.2009.09.004.

Wangid, M. N. (2004). Peningkatan prestasi belajar siswa melalui self-regulated learning. [Improving student learning achievement through self-regulated learning]. Cakrawala Pendidikan, 23(1), 1-19. doi:10.21831/cp.v1i1.4858.

Welpe, I. M., Sporrle, M, Grichnik, D., Michl, T., \& Audretsch, D. B. (2012). Emotions and opportunities: The interplay of opportunity evaluation, fear, joy, and anger as antecedent of entrepreneurial exploitation. Entrepreneurship Theory \& Practice, 36(1), 69-96. doi:10.1111/ j.1540-6520.2011.00481.x.

Wood, M. S. (2017). Misgivings about dismantling the opportunity construct. Journal of Business Venturing Insight, 7(1), 21-25. doi:10.1016/j.jbvi.2017.01.001.

Zampetakis, L. A., Kafetsios, K., \& Moustakis, V. (2017). Using emotional persuasion for changing attitudes towards entrepreneurship: An interpersonal perspective. Journal of Business Venturing Insights, 7(1), 50-54. doi:10.1016/j. jbvi.2017.03.002. 